\title{
11. Situated Knowledge or Ego (His)toire?: Memory, History and the She-Migrant in an Imaginary of 'Terra Nullius'
}

\author{
Jane Haggis
}

\section{En/countering Ego-Histoire}

I admit I had not come across the term ego-histoire until sent a flier for the conference that stimulated this volume. My attention was caught immediately, however, as I crudely translated the subtlety of the French phrase into English as 'self-history'. This seemed to echo precisely my own broad methodological engagements with the relationship between myself as feminist scholar and the subjects of my writing. What story was I telling, from where, and whose? Did ego-histoire offer another avenue to pursue my politico-intellectual search for an ethical writing practice sufficient to render the past and present in tones appropriate to a post-colonising and (hopefully) cosmopolitan future?

My questions reflect an early and long engagement with feminist scholarship concerned to query the universalising that had written women out of 'His/ story', science, social science and the humanities. All these institutionalised disciplines distinguished narratives of evidence and objectivity that scripted out the partiality of the male viewpoints it privileged (see, for example, Bock 1989; Haraway 1988; Scott 1988; Bordo 1987; Harding 1986; Hartsok 1998; FoxGenovese 1982; Okin 1979) This awareness of the particularity buried under universalising claims led feminist scholars in the 1980s to engage with reflexivity and the methodological implications of partiality buried in claims to knowledge (Lather 1988; Smith 2008; Stanley \& Wise 1983). An acute awareness of difference propelled out of the political and intellectual engagement between white women and women of colour (for example, Mohanty 1984; Amos \& Parmar 1984; Anzaldua 1987; hooks 1982; Minh-ha 1989) both presaged and meshed with the post-colonial and postmodern critiques of western-centric universalising in knowledge production (Spivak 1985; Said 1978; Butler \& Scott 1992). This intellectual genealogy affirmed the particularity of knowledge - the scholarly exegesis was always a view from somewhere; specific, particular and partial, rather than omniscient. The trick is authorial-replacing the godlike 'voice from everywhere and nowhere' with a transparent awareness of multiplicity — what Ellen Barklay-Brown, drawing on African American English, 
referred to as 'gumbo ya ya' to describe histories 'occurring simultaneously, in connection, in dialogue with each other. To relate their tales separately would be to obliterate the connection' (Barklay-Brown 1992, p. 297).

Nora's concept of ego-histoire thus piqued my interest in terms of my existing engagement with the challenge of perspective and writing engaged with in the interstices between history, feminism and post-structuralism. As I look back across two decades of writing and publishing in the specific areas of gender and imperialism and critical race and whiteness studies, the consistent thread is a concern to explicate the link between 'history' and (my)self. Or, to put it another way, the thread has been between private biography and social inquiry within which social and cultural history, along with sociology, anthropology and psychology, take shape (Mills 1970; Clifford 1986; Steedman 1986). This project seems to echo Nora's own-to rework, rethink, reimagine the relationships between the past and the present. Ien Ang's trope of entanglement encompasses the sense in which the methodological imperative is not simply an awareness of how self connects with one's 'History', but the ways in which both self and History are constrained by the entanglements with those other stories Barklay-Brown captures in 'gumbo ya ya'. The methodological journey is from a disruption of singularity to an awareness of partiality, plurality and perspective that does not reconstitute a unity. My narrative of self necessarily demands to be deconstructed to reveal its 'entanglements', complicit and resistant, with other stories of class, race, geography and nation, that work to take the singularity out of History and replace it with a messy tale, unsure of its origins or its trajectory beyond the objective of transparency and (perhaps) an ethical accountability for the 'H/his/her story' so produced.

\section{Situating The Un-disciplined Her-storian and History}

In hindsight, history shapes my intellectual journey but always in ways that skirt the formal discipline of History. I am a scholar of no fixed disciplinary abode, who writes and teaches across the past and the present, sometimes conveniently labelling my work as historical sociology/anthropology, feminist historiography, critical race scholarship, cultural studies, and so forth, but always knowing it somehow refuses the neat labels of institutionalised knowledge-production (Wallerstein 2001). This refusal is wilful - a conscious act, not of rebellion however, but of perspective; itself a consequence of a marginality constituted through class, gender and migration that re-centres around racial privilege.

The first of my transnational extended family to enter university, I did so out of an inchoate ambition shaped by a family respect for 'cleverness' formed by a BBC 
attempting a broader engagement beyond the confines of class; a grandmother sent out to scrub doorsteps at 12 rather than take up a school scholarship; and a mother who was of the first generation to benefit from a public secondary education in the immediate post-war years. A primary education informed and funded by a London County Council committed to foster an aspirational working class provided a more personal engagement with learning for its own sake, beyond utilitarian concerns of earning a living. Somehow this sensibility survived the journey to rural Australia and subsequent immersion in an education system uneasily transforming itself from a civilising antidote to the savagery of the bush, into an integrated system of socio-economic mobility focused on civility, urbanity and profession. Arriving at university by virtue of a scholarship required a refusal of the teaching pathway - female and paid - to embark on a journey into a campus still largely untouched by mass immigration or the incursions of a publicly educated working class. I am still able to conjure up the overpowering feeling that permeated that first university year: of being a stranger without compass or language, rendered dumb. Failure and retreat completed that first encounter with academe. Retreat into a family faith in the autodidact redolent perhaps of an organic intellectualism figured through workers education and unionism.

Second time round that same campus was transformed into a polyglot of migrants or their offspring, women, and mature age students all grappling with a politics and history curriculum informed by the academic New Left, and the beginnings of institutionalised women's and feminist studies. A new maturity acquired through work, travel and marriage, gave me a voracious appetite for learning. I read every item on each reading list; endlessly discussing ideas in the 'Women's Room' with friends who had cut their teeth on Greek or Italian communist and anarchist ideas argued over family dinner tables; or anti-imperialism inspired by Lebanese and Palestinian diasporas. Histories of anti-colonialism and revolution, political theory immersed in the debates of the Anglo-European New Left, Virginia Woolf, Rosa Luxembourg and contemporary socialist-feminists stoked the fire of my indignation and intellectual curiosity. Where marginality remained was in my identification with the usual objects of study: the 'workers', the 'people', 'ordinary people'. Translating analysis back to my other life, as a family member of an unskilled worker's family in a semiindustrial rural town, I felt the oppression of 'false consciousness', that theythe writers, lecturers, intellectuals and activists - knew us better than we knew ourselves. Family debates about my ideas and our lived realities taught me to look underneath the categories, to value the resistant complicities, talking back, and anterior knowing of everyday popular cultures.

I was ripe for the Birmingham School of cultural studies which, coupled with post-colonial feminisms and subaltern studies, shaped my postgraduate years. 
Those years were themselves a kind of reverse migration, to a northern university in the land of my birth where the familiarity of institutional class cultures, replete with southern privilege, gave a regional dissonance to another layer of marginality, as I was viewed as a parochial colonial always '20 years behind'. The working class migrant now found herself fixed by a metropolitan gaze that refuted her 'being at home' and confused any sense of belonging. I seemed caught in a never-ending in between, not quite there, never fully here, which inflected my intellectual pathway into colonial studies via history, sociology and anthropology. Situating the intersections of class, gender and racial hierarchies methodologically and analytically within feminist historiography drove my doctoral studies. Early publications (Haggis 1998a, 1998b) document my struggle to write history dialogically, as an interpellation between text, subjects and authorial representation that might resist the seductions of colonising the other as historical subject or contemporary representation.

Ironically, being misrecognised as a colonial myself kick-started a belated awareness of my own situated knowledge at the heart of empire. Eventual relocation to Australia made this more rather than less awkward to address. The culture wars of history and belonging that stalked the 1990s begged the question how the 'white queen' (Haggis \& Schech 2001) was to situate herself in the settler-colony that stubbornly resisted the post-colonising. Professionally, exigencies of geography, opportunity and un-discipline meant I found myself teaching and researching in the field of Australian sociology, then largely untouched by postcolonial studies, Indigenous scholarship or critical race and whiteness studies. Multiculturalism and ethnicity marked the disciplinary borders, as one Australian Sociological Association committee informed me 'race' was too controversial, by implication best left to the anthropologists. On the other hand, more than one Australian historian commented that my work was 'too theoretical' to be 'proper history'. Thus a focus on privilege and racialising the white self reinscribed a sense of, as one colleague couched it, 'being on the margins' of discipline and profession. This sense of marginality and un-discipline is descriptive of my discomfort in a neo-liberal professionalised academy that thrives on borders and boundaries. It is not dissimilar to the sense of being outsiders that Passerini and Geppert identify in their contributors, including Pierre Nora himself. Quite plausibly, they see this 'self-fashioned marginality' as both historically specific to the '1968 generation' and perhaps 'a leitmotiv of the entire genre' (Passerini \& Geppert). I cannot claim a temporal affinity with Nora and his peers, but do suggest marginality, whether self-fashioned, structural or (most likely) a bit of both, is what gives ego-histoire and situated knowledge

\footnotetext{
1 This quote is verbatim from a conversation with a leading academic about whether my Australian honours prepared me for doctoral studies at an English university.
} 
their critical edge as methodologies of interrogation. To demonstrate this point, in the rest of this paper, I explicate how I situate the 'white queen' in the (never quite) postcolonial of Australia.

\section{Re-routing/Rooting the She-Migrant}

In the early 2000s I attended a whiteness studies conference in Queensland where a workshop was run by Indigenous and non-Indigenous scholars. To start the conference, and reflecting Indigenous protocols of placement and yarning, as well as feminist politics of situating selves, we were asked to break into small groups and tell our stories of genealogy. ${ }^{2}$ In my group, both Indigenous and white women briefly recounted their life pathways in terms of origins. For the Indigenous women these turned on country and language-group, interrupted for some by the brutalities of the stolen generations and/or removal from ancestral country, occasionally complicated by border crossings of marriage with German, Irish, Maori, Pacific Islander, Polish or Chinese (great-)(grand-) fathers. The white women told themselves through their connections with that same Aboriginal narrative, the tempo paced around hints of Aboriginal relatives and/or a guilty complicity in colonialism's terrors of massacre, incarceration and loss as well as a knowledge of antecedents buried in the migrancy of convicts, gold, land or persecution from which pioneer legends are construed. I found myself stuck; stuck in the mud of the Thames. I had no connection with the Australian pasts, Indigenous or pioneer. Nor did I have any multi-generational sense of belonging, place and origin as a migrant. Like many of the urban English working class of the early and mid-twentieth century, we had no origin story beyond the imperial and war time narratives of a jingoistic parochialism that averred our sense that this place (South London) was for us and not them. ${ }^{3}$ My paternal grandmother, on returning to England in the early 1970s from Australia and being told that her social housing entitlements were attenuated because of her overseas sojourn, retorted in outrage to the young 'Pakistani' clerk: 'I've been through two world wars for this country', which indeed she had; making bombs as a 14-year-old in the first and driving a crane through the Blitz in the second. This slip of memory is revealing in so far as it shows both the source of her sense of entitlement and ownership - in a national narrative of

\footnotetext{
2 As an anonymous reviewer of this chapter pointed out, this form of personal chronological recounting of self is a post-conquest form of Indigenous storying, at least in part a response to the expectations of the nonindigenous inquiry system.

3 Alistair Bonnett's argument about the whitening of the working class reflects my familial history, that those once referred to as the 'heathen' of the urban slums were gradually brought within the auspices of the state's project of a raced modernity and the nation's sense of imperial mission during the late-nineteenth and early-twentieth century (Bonnet 2000).
} 
war rather than 'race' pure and simple (although 'Pakistani' refuses the possible claim of that clerk through birth, empire or citizenship) — and its limits for my ego-histoire.

My history of oozing from the London mud went no further than grandparents and stories of a 'foreign woman' to explain the 'touch of the other' that might be revealed in black hair, brown eyes, sallow skin. The phrase is one from my South London childhood, which I have been unable to track down beyond a memory of my paternal grandmother using it to refer to people who looked a bit different and to her own (or perhaps her deceased husband's) story of the 'foreign woman' to explain the 'dark' features of her own children, and 'the family madness' referring to the 'highly strung' volatile aspects of family personalities. My mother - also from South London and a somewhat more respectable 'steady wage' segment of the working class-recalls the phrase being used to refer to people who were perhaps suffering imaginary illness symptoms or acting 'a bit mad', but has no recollections of it ever being used with racial or 'colour' overtones. It is easy to imagine how the two meanings might blur, if one thinks of those tropes in nineteenth and early-twentieth century English culture in regard to miscegenation and madness indelibly rendered by Charlotte Brontë in Jane Eyre. How does such a narrative place me, the she-migrant, as her-storian in an Australian narrative of origin and belonging? I am caught between the imperialist jingoism of the working class England I claim birth right to and the imaginary of terra-nullius shaping Australia's national histoire/History. A worn-out template of English indigenousness deployed by the likes of the National Front that denies the hybridity of its History/histoire, or a neurotically possessive whiteness (Moreton-Robinson 2004) constantly attending to its 'border wars', whether figured as those who come by boat, or the 'priority of the prior' (Povinelli 2011, p. 15). Is it possible to have a histoire/history that has no start or finish? No sense of being in the right (or my) place?

Invasion and migration mark my sense of histoire differently. Tracked through feminisms' emphatic refusal of objectivity, Nora's concept is caught on a positivist assumption of externality as necessary for the Historian to make History out of her ego-histoire. This assumes the power is in the eye of the beholder (the alter-ego?) but, as Dorothy E. Smith observed of sociology, the power is in the 'language practices ... that achieve the transition from being among people to being above them' (Smith 2008, p. 418). Yet, as the work of Foucault, Said, Scott and White demonstrates, no simple demotic of democracy can frame even the feminist's text. The her/historian is rendered not outside, or at one, with the self of histoire or History, but the creator of meaning in both her histoire and history. White argues for an ethical practice of historiography that (re)embraces the 'ethically rich traditions of literary expression' (White 2005, p. 338). There can be no 'History', only histories informed by a 
poetic sensibility - the rhetorical styles chosen by the historian with which to plot the 'facts'. These are histories that claim meaning rather than knowledge for their artefact. This renders ego-histoire very differently to Nora. From such a post-structuralist and feminist standpoint, the ego-histoire of the historian is not external to the History Nora hopes it will rework. History does not make the ego-histoire. Instead, the self-story becomes a constitutive part of both the $\mathrm{H}(\mathrm{h})$ istorian and her 'H/history'. The very first seminar I gave on my then doctoral work, subsequently published in a volume on feminist methodologies (Haggis 1990), described the intersection of biography and history that shaped my intellectual journey to that point. Separating out my history from my histoire was unimaginable to me. My task, methodologically, was not to remove my 'self' in some kind of objective facticity, but to make transparent the way my story, as ego-histoire, necessarily constructs the history I produce as partial, not all-knowing. ${ }^{4}$ In Nora's ego-histoire there is no positioning of the $\mathrm{H}(\mathrm{h})$ istorian beyond the tension between the individual and the collective. Who is the 'we' that the ' $\mathrm{I}$ ' belongs to?

\section{Moon-landing}

In 1964 'swinging London' was apparent even in Lower Tooting. Youth's pop culture already ensured my younger sister and I had our first Beatles albums, reflecting our parents' earlier engagements in the nascent teen culture of the immediate post-war years. We sat around the TV as a family and watched Jukebox Jury and Ready, Steady Go! as well as the more sedate London Palladium and, of course, Dr Who. Knock down Ginger on bright summer nights and tea parties on the pavement marked our play time, along with visits to museums and holidays with donkey rides and Norman ruins to shoot arrows from, not to mention Charlie Drake's facile hit song, 'My Boomerang Won't Come Back', to sing in the motor bike's side-car on the way there.

What to make of a place then, with no television, a stuffy BBC clone for a radio, unpaved roads and wood-fired baths? Of a place where, even in those first few months, ghosts flitted past us-Boandik Drive, Blackfella's Caves, Piccaninny Ponds, a dusty window full of strange artefacts, new words in the school yard such as 'lubra lips' and 'Abo'. A place where a talk, dark-skinned girl defiantly refused the shaming imposed by the Grade Five teacher on her standing in the front of the class, her face blank and fierce in the eyes of the alien child, myself, already fearful of a state school culture of corporal punishment administered freely in the classroom.

4 For a fuller discussion of this point, see (Haggis 1998, 2012b). 
What to make of a school-friend who whispered about her great-greatgrandmother's diary recounting how she walked for days through the bush, accompanied only by an Aboriginal guide, as we learned our history lessons about Cook and Gold and Simpson's Donkey. Of a youth culture mired in illicit sex and not so illicit drinking, in which 'gangbangs' were openly talked about and 'shotgun weddings' struggled to survive against the lure of the 'widow's pension' and a kind of independence as a 'mole', always liable to predatory invasions into their housing trust ghetto by men on the lookout for easy sex; outcastes from small town respectability. This at the same time as a different stolen generation, of white babies taken from their young mothers, was secreted away.

What to make of this as a histoire for my History? The memory of that tall girl in my grade five class indelibly impressed on my emotional retina infused with shame - my shame for bearing witness in silence but the discomfort of not knowing from whence I earned this shame. A child's response, perhaps, to an injustice s/he does not understand; the vocabularies that animate it, she is ignorant of; the discomfort of the migrant turned settler. What is the relationship of the migrant to the past? Ghassan Hage convincingly argues that the failure of the colonial project in Australia captures the migrant, even the non-Anglo, 'not quite white' migrant, in the never quite decolonised stasis of the nation-state (Hage 2001). A similar point is made by Nicolacopoulos and Vassilacopoulos, although they centre race possessiveness rather than, as Hage argues in White Nation, a conflated nationalist sense of ownership. Both arguments pin the late- or new-comer as coloniser in relation to the dispossessed Indigene just as much as the multi-generational 'Aussie' (Hage 1998). Of course, through the articulation of my working class memories of belonging in a jingoistic imaginary of empire, I am already implicated in this failed colonial project, even before I make my moon-landing.

My gaze is fractured between the imperial metropolitan who already 'knows' the colonial, and the parochial colonial herself. How do I position myself and plot this in terms of those eerie place-names and that tall dark girl in my Year Five memory? The tropes available have already been mapped through the contours of critical race and whiteness studies: the benevolent goodness of whiteness, the guilty burden of the traitorous white, and the moral smugness of the politically correct (Haggis 2004). None engage sufficiently with the complicity embedded in my histoire or the shame infusing my memory, shame tinged with a kind of horror. As I look back to that moonscape of rural Australia I found myself transported to, I seem to discern the longue durée of the colonial frontier; how else to understand the atmospherics of violence that suffuse my memories of classroom and school yard, of late childhood and early youth. How else to understand the predatory and rapacious heterosexual masculinity such that 'black velvet' and 'lubra lips' not only continued their savage racism, but 
easily transplanted onto the mole, slut and unmarried mother a fearsome sexual conquest that made pre-pubescent girls fair game. This, in part, explains for me the depth of silence and secrecy that haunts the stories of maternity for many young women of that era, especially from 'respectable' families inhabiting the borderland between grazier-ocracy and those white trash/blackfella creolised spaces productive not of positive hybridity (Hughes 2012) but the sordid violence of degradation and marginality.

\section{(Un)Settled Entanglements}

The little extended family of six that arrived by plane as 'ten pound tourists' is now a mob of 20 radiating out from those south London streets to encompass Ngarrindjeri, Illongot, Scottish and multi-generational, Anglo-Celtic pioneer stock. My family's rootedness now encompasses blackness as well as whiteness in ways that 'talk up' to the she-migrant's histoire, extending the frontier trope to a new kind of guerrilla war across the lines of fractured families.

'Hey Granma. Look! Dirty blackfellas.' My four-year-old nephew's words stopped us. Silenced, our eyes clung to each other's as we motored lazily down the hot Sunday morning quiet of the Adelaide highway. 'Hmmm, yeah, look over there, d'ya see that cop car? See the light on top and the big writing? Who do you reckon they're after?' Tension released as the child and his brother turn to see the police vehicle pulled up beside us at the traffic lights. Later, once the child is asleep, we pick at the entrails of that moment, furtive, unsure. 'G- told me once that her mum whacked her over the head and sent her flying, at a pub in $\mathrm{M}$ - when she was about thirteen, when this really dark bloke came up to talk to her. Her mum told her to stay away from the "bush blacks", said they were wild and went after young girls to marry.' This seemed to explain the child's words as he watched the two Aboriginal men, beanies on head, their dress, demeanour and embodiment marking them on the Adelaide street as 'remote', from 'up north'. But what if behind his words lurked the overheard racisms repeated by a child still unmindful of the gaze that fixes him as 'dirty blackfella' too? Or, perish the thought, perhaps this was the vocabulary he thought you spoke in whitefella land, with 'us', another language learned from that spoken in his Nunga family. What then of our silence? I recall another access weekend spent with my mother and her two Nunga grandsons: 'Granma, Nanna says you're just a dumb white.' 'She's probably right', the response came with nary a pause. About being dumb or being white or both? I puzzle, reluctant to ask my mother to recollect her words and their meaning-memory. And what of that comment, relayed with a wide-eyed curiosity as to its effect. The wilful wanting to know of a child caught between family wars captures the essence of the 'history wars' also rendered in the language of colour as black or white. 
As I write, years have passed; two strong young Nunga lads come of age. Time, tragedy and great-grandchildren work their magic. Two families meet at births, weddings, anniversaries, festivals and those other comings and goings of keeping in touch. Photos litter Facebook along with shout-outs to 'the Haggis mob'. Facebook also brings long-distant half-remembered cousins into focus, on a visit from an England they blog in terms of St George's Day and a visceral ethnic patriotism. Kin proves thicker than terroir, however, as they warmly greet this polyglot extended family, stretched now not only over the temporal reach of Indigeneity but an(other) migrancy that also produces great-grandchildren, rooted deep in the intricate mosaics of Mindanao and a half-forgotten Spanish empire. An empire remembered in a great-great-great-grandmother whose effect within my histoire is uncanny, paralleling the 'foreign woman' conjured by my grandmother to explain that 'touch of the other'. Is my ego-histoire replotted then? Does it shift from the brutality of frontier to the ease of reconciliation and a twenty-first-century cosmopolitanism? Is it suggesting a post-(colonial) nation as a 'contemporary history'? (Nora 2001).

The unease embedded in my recollections of my Nunga nephew's childhood remains however, caught in the hyper-reflexivity of my mother, as she rakes over the coals of another happy gathering. The echo of that early epithet, quite possibly now gone from an elderly memory, caught in her 'did I put my foot in it?' Or the awkward, 'shall we ring them or wait for them to ring us?' conversations between her and I as we set up another Christmas. A different set of tensions emerge in the interstices of a wedding held between southern Mindanao and the western suburbs of Adelaide. Embracing the exotic in the Australian-Pilipina bride leaves a mother bemused and offended by the reverseracism of a mail-order mother-in-law, perhaps inured in the protective husk of the always-already-raced 'Asian woman' (Ang 1996). Entanglement brings not reconciliation but the awkwardness of the contact zone to my ego-histoire.

My ego-histoire must remain fraught with doubt, anxiety and unease in order to escape the frontier and enter at least the possibility of the impossible (Watson 2007). 'History' as a discrete, defined disciplinary practice or collective structure does not serve. I refuse 'Historian' and claim, perhaps, 'historian', writing always from the particularity of some one's history, a history never external to the narrator or the narrated. Slowly, this is evolving into a method of historiography grounded in an ethics of entanglement: of partiality and incompleteness approximating perhaps Joan Scott's prescription:

For the historian to ignore the stories themselves ... It is to refuse to engage with the novelty of the old, the strangeness of the new, or the irreducible difference of the other - to insist instead on sameness, on the comfortable familiarity of the already known (Scott 2011, pp. 204-205). 


\section{References}

Amos, V \& P Parmar 1984, 'Challenging Imperial Feminism', Feminist Review, vol. 17, pp. 3-9.

Ang, I 1996, 'The Curse of the Smile: Ambivalence and the "Asian" woman in Australian multiculturalism', Feminist Review, vol. 52, pp. 36-49.

Anzaldua, G 1987, Borderlands: La frontera - The new mestiza, Spinsters/Aunt Lute Book Company, San Francisco.

Barkley-Brown, E 1992, “What Has Happened Here": The politics of difference in women's history and feminist politics', Feminist Studies, vol. 18, no. 2, pp. 295-312.

Bock, G 1989, 'Women's History and Gender History: Aspects of an international debate', Gender and History, vol.1, no. 1, pp. 7-30.

Bonnett, A 2000, White Identities: Historical and international perspectives, Prentice Hall, Harlow.

Bordo, S 1987, The Flight to Objectivity: Essays on Cartesianism and culture, State University of New York Press, Albany.

Butler, J \& J W Scott 1992 (eds), Feminists Theorize the Political, Routledge, New York and London.

Clifford, J 1986, Writing Culture: The poetics and politics of ethnography, University of California Press, Berkeley.

Curthoys, A 1999, 'Expulsion, Exodus and Exile in White Australian Historical Mythology', Journal of Australian Studies, vol. 23, no. 61, pp. 1-19.

Derrida, J 2001, 'Time and Memory, Messianicity, and the Name of God', in P Paton \& W Smith (eds), Deconstruction Engaged. The Sydney Seminars. Sydney, Power Publication, p. 67.

Fox-Genovese, E 1982, 'Placing Women's History in History', New Left Review, vol. 133, pp. 5-29.

Hage, G 2001, 'Polluting Memories: Migration and colonial responsibility in Australia', in M Morris \& B de Bary (eds), 'Race' Panic and the Memory of Migration, Hong Kong University Press, Hong Kong, pp. 323-62.

Hage, G 1998, White Nation: Fantasies of white supremacy in a multicultural society, Pluto Press, Annandale. 
Haggis, J 1998a, "'A heart that has felt the love of God and longs for others to know it": Conventions of Gender, Tensions of Self and Constructions of Difference in Offering to be a Lady Missionary', Women's History Review, vol. 7, no. 2, pp. 171-192.

Haggis, J 1998b, 'White Women and Colonialism: Towards a non-recuperative history', in C. Midgley (ed), Gender and Imperialism, Studies in Imperialism series, ed. John McKenzie, Manchester, Manchester University Press, pp. $45-75$.

Haggis, J 2004, 'Beyond Race and Whiteness?: Reflections on the new abolitionists and an Australian critical whiteness studies', Borderlands, vol. 3, no. 2, Available at: http://www.borderlands.net.au/vol3no2_2004/ haggis_beyond.htm.

Haggis, J 2012a, 'White Australia and Otherness: The Limits to Hospitality', in A Hayes \& R Mason (eds), Cultures in Refuge: Seeking sanctuary in modern Australia, Ashgate, Surrey, pp. 15-30.

Haggis, J 2012b, 'What an "Archive Rat" Reveals to Us About Storying Theory and the Nature of History', Australian Feminist Studies, vol. 27, no. 73, pp. 289-295.

Haggis, J 1990, ‘Gendering Colonialism or Colonising Gender?: Recent women's studies' approaches to white women and the historical sociology of British colonialism', Women's Studies International Forum, vol. 13, No. 1-2, pp. 105-115.

Haggis, J \& S Schech 2001, 'Meaning Well and Global Good Manners: Reflections on white western feminist cross-cultural praxis', Australian Feminist Studies, vol. 15, no. 33, pp. 387-399.

Haraway, D 1988, 'Situated Knowledges: The science question in feminism and the privilege of perspective', Feminist Studies, vol. 14, no. 3, pp. 575-599.

Harding, S G 1986, The Science Question in Feminism, Cornell University Press, Ithaca.

Hartsock, N 1998, The Feminist Standpoint Revisited and Other Essays, Westview Press, Boulder.

Hooks, Bell 1982, Ain't I a Woman: Black women and feminism, Pluto, London.

Hughes, K 2012, 'Microhistories and Things that Matter: Opening spaces of possibility in Ngarrindjeri country,' Australian Feminist Studies, vol. 27, no. 73 , pp. $269-278$. 
Hunter, J 2010, 'Women's Mission in Historical Perspective: American Identity and Christian Internationalism', in B Reeves-Ellington et.al. (eds), Competing Kingdoms: Women, mission, nation, and the American Protestant empire, 1812-1960, Duke University Press, Durham and London.

Lake, M \& H Reynolds 2008, Drawing the Global Colour Line: White men's countries and the question of racial equality, Melbourne University Press, Carlton.

Lather, P 1988, 'Feminist Perspectives on Empowering Research Methodologies', Women's Studies International Forum, vol. 11, no. 6, pp. 569-581.

Mills, C W 1970, The Sociological Imagination, Penguin, Harmondsworth.

Minh-ha, T T 1989, Woman, Native, Other: Writing, postcoloniality and feminism, Indiana University Press, Bloomington and Indianapolis.

Mohanty, C T 1984, 'Under Western Eyes: Feminist scholarship and colonial discourses', Boundary 2 vol. 12-13, pp. 333-358.

Moraga, C \& G Anzaldua 1981 (eds), This Bridge Called My Back, Kitchen Table, Women of Color Press, New York.

Moreton-Robinson, A 2004, 'The Possessive Logic of Patriarchal White Sovereignty: The High Court and the Yorta Yorta Decision', Borderlands e-Journal, vol. 3, no. 2. Available at: http://www.borderlands.net.au/ vol3no2_2004/moreton_possessive.htm.

Nora, P 2001 'L'Ego-Histoire est-elle Possible ?', Historein, vol. 3, pp. 19-26.

Okin, S M 1979, Women in Western Political Thought, Princeton University Press, Princeton.

Papastergiadis, N 2004, 'The Invasion Complex in Australian Political Culture', Thesis Eleven, vol. 78, pp. 8-27.

Passerini, L \& A C T Geppert 2001, 'Historians in Flux: The concept, task and challenge of ego-histoire', Historein, vol. 3, pp. 7-18.

Povinelli, E 2011, 'The Governance of the Prior', Interventions, vol. 13, no. 1, pp. 13-30.

Ravenscroft, A 2012, The Postcolonial Eye: White Australian desire and the visual field of race, Ashgate, Surrey.

Said, E W 1978, Orientalism, Pantheon Books, New York. 
Ngapartji Ngapartji, In Turn, In Turn: Ego-histoire, Europe and Indigenous Australia

Schech, S \& J Haggis 2004, 'Terrains of Migrancy and Whiteness: How British migrants locate themselves in Australia' in A Moreton-Robinson (ed.), Whitening Race: Essays in social and cultural criticism, Aboriginal Studies Press, Canberra, pp. 32-47.

Scott, J W 1988, Gender and the Politics of History, Columbia University Press, New York.

Scott, J 2011, 'Storytelling', History and Theory, vol. 50, pp. 203-209.

Smith, D E 2008, 'From the 14th Floor to the Sidewalk: Writing sociology at ground level', Sociological Inquiry, vol. 78, no. 3, pp. 417-422.

Spivak, G C 1985, 'Three Women's Texts and a Critique of Imperialism', Critical Inquiry vol. 12, no. 1, pp. 243-261.

Stanley, L \& S Wise 1983, Breaking Out: Feminist consciousness and feminist research, Routledge \& Kegan Paul, London and Boston.

Steedman, C 1986, Landscape for a Good Woman: A story of two lives, Virago, London.

Watson, I 2007, 'Aboriginal Sovereignties: Past, present and future (im) possibilities', in S Perera (ed.), Our Patch: Enacting Australian sovereignty post-2001, Network Books, Perth, pp. 23-43.

Wallerstein, I 2001, Unthinking Social Science: The limits of nineteenth-century paradigms, Temple University Press, Philadelphia.

White, H 2005, 'The Public Relevance of Historical Studies: A reply to Dirk Moses', History and Theory, vol. 44, no. 10, pp. 333-338. 
This text taken from Ngapartji Ngpartji: In turn in turn:

Ego-histoire, Europe and Indigenous Australia

Edited by Vanessa Castejon, Anna Cole, Oliver Haag and Karen Hughes,

published 2014 by ANU Press, The Australian National University, Canberra, Australia. 